\title{
PDGFRA Gene Amplification
}

National Cancer Institute

\section{Source}

National Cancer Institute. PDGFRA Gene Amplification. NCI Thesaurus. Code C96868.

A molecular genetic abnormality indicating the presence of multiple copies of the PDGFRA (platelet-derived growth factor receptor, alpha polypeptide) gene. 